\title{
THE INFLUENCE BETWEEN STUDENTS' LANGUAGE POTENTIAL WITH THEIR OWN DIALECT
}

\author{
Surya Adi Kusumah ${ }^{1}$, Silpia Rahayu², \\ ${ }^{1}$ IKIP Siliwangi \\ ${ }^{2}$ IKIP Siliwangi \\ ${ }^{1}$ adikusumah@student.ikipsiliwangi.ac.id, ${ }^{2}$ silpiarahayu@ikipsiliwangi.ac.id
}

\begin{abstract}
This study was conducted to obtain information about dialect in student's potential whether it could be decided to speak fluently or not. Taken from one of institute which appear the idea to analyze the problem, the main instrument to collect the data was questionnaire and transform it to be narrative which aimed this research use qualitative method. From 4 dialects were used by the students namely Bataknese, Minangnese, Javanese and Sundanese which they use when speaking, especially the dialect's intonation usage within English speaking. This will be impact on the learning method that might be constant rather than variable within English intonation usage. The questionnaire result will prove about the problem that occur in amid of the classroom. Moreover, this research has been supported from more than 10 theories instead. It contains many different topics related dialect and student's potential in speaking. From finding, the researcher obtained the data that talking with person who have strong dialect was not such a big problem to understand what does the person mean. The result is not change the dialect the person used, the only thing is practice English intonation to be better and develop the person's language potential to adjust the language the person speaks.
\end{abstract}

Keywords: Dialect, English Intonation, Student's Potential

\section{INTRODUCTION}

Considering students' potential is not just mark the speaking fluently then able to deliver the information which is well organized. Many of requirements should be fulfilled by learners who are studying language such as interpretation, pronunciation, fluently and so on. Word is the basic foundation that should be exist in language cause without word the sentence will not came out to be used (Aprianti \& Parmawati, 2020). These things could be valuable for seeing your capability in speaking (Arjuna, 2016). This research mention interpretation as a measurement on how critical thinking is very important to cover the ability for making the ideas become a sentence that could be well organized. Furthermore, pronunciation is needed for a speaker for making easily understanding to those listeners who are catching each word clearly therefore the aim is well received. And also the manner usually related to dialect which mean a form of language that could be seen by manner of speaker when speak. Finally, fluently is a complement in which a listener could judge whether or not the speaker is well experienced in speaking English.

Students' potential is a certain of capability in which students will be able to develop their soft or hard skill in order to emerge self-enthusiasm to do the dominant thing than other (Mawadda Warohma et al., 2018). This also could influence other people really understand the potential which having by each person through measuring him by his disadvantages that appeared when it was exhibited. 


\section{Volume 3, No. 6, November 2020 pp 680-688

Dialect is form of a language used in part of a country, county and rural nor urban the city. Every single person who are living in a certain of urban have a dialect although those people are in the same of country. (Li et al., 2018) stated that dialect is a particular human habit of each person who are living in a group that have same behavior talking with the same language and produce a same dialect but when talking with a person who is living in different area, their dialect totally different.

This research attempt to examine, does dialect influence students' potential when they are speaking? this could judge a person who could speak English fluently but he has a different dialect could not be marked as a good speaker. It rarely for a speaker in a certain of occasion to make a different dialect. A number of people could not catch the idea of the speaker sometimes and rather disturbing a listener when listener is attempting to receive the information. In Indonesia have a number of rural areas in the same province that is West Java and having a same language but when they are talking, the dialect is different. This problematic could be investigated by interview some people who had found the same problem.

Dialect is variation of the same language through geographical region or social group. It has so many different in several linguistics such as phonological, grammatical, orthography and different vocabulary at most (Li et al., 2018). Dialect is often used in the classroom by other people who always used their own language in own rural therefore it is quite difficult when they are attempting to change their own dialect even when they talk in English. Primarily in the classroom when a student becomes a presenter on his own presentation, his friends are paying attention him to get the brief information of the material he presented sometimes it is quite difficult because of their dialect is disturbing the audience. Compare with the home area when he talks with their social interaction with the same dialect and language that he uses. Certainly their friends are easily to catch the point, because there is no problematic that could disturbing their friends to get the information. In this case, student will learn social interaction that could affect the learning outcome and how it could leverage the student's learning experiences which could engage them to do more practice (Kessler, 2018). Student express in relevant utterances which is understood conveniently and acceptable level of language accuracy that is what does the language really mean (Arjuna, 2016) .

In school, student would find the variant level of language accuracy that every single student has. (Mallinson et al., 2011) refer to school systems' use of standardized English as 'Standard English, formal English, School English, academic English, proper English, educated English, good English and correct English". These standardized speakers are noted to have privileges that non standardized speakers do not - namely, that the dialect they speak is also more closely related to the preferred communicative style of the academic discourse community (Mallinson et al., 2011). Using an academic English is one of a system that being used in the college therefore it should be applied in the classroom.

\section{Dialect's Problematic Facing Language Potential}

The researcher recognized 4 different dialects in the classroom namely Javanese, Minangnese, Sundanese, Bataknese. These dialects are chosen because in the class there are some students who were using these dialects. Their characteristics will appear while they are speaking. First on Minang, it has tendency to pronounce the letter of /e/ and often speak quickly. Second on Bataknese, most Bataknese speak highly intonation. Sometimes people are shocked because 
they seem like bad tempered. Bataknese tend to pronounce the letter of $/ \mathrm{t} / \mathrm{using}$ emphasis after every sentence. Third on Javanese, many Javanese pronounce these letters such as $/ \mathrm{b} / \mathrm{j} / / \mathrm{d} /$ seems spurt, they commonly mention this as medok (Mawadda Warohma et al., 2018). Moreover when Javanese are speaking, the letter of /h/ often be added for example let say adhus from the word adus which mean take a bath and another thing is pranasal for example the word bali which means get home often be pronounced [mbali]. Finally on Sundanese, it has phonemes that could be its own characteristics making it different with others such as /e/, /a/ and /eu/ (Rahmawati \& Lestari, 2018). The characteristics could be exhibited to other that where do they come from and this could be something doubt for those people to convince them in order to be professional in term of their own speaking ability. In fact, many people have learnt to be professional in which they could show their skill in speaking especially to convince those audience for having good impression in the very first beginning. This is very important that language could marking others in term of their character and also their education. Problematic is a case that every mankind belief it belongs to every single person in the world but only for people who could solve the problem that they could achieve something in the end for facing the problem. In the office for example that always do a presentation which is aimed for breaking down several problem that belong to the corporation. A presenter should be a professional means that he qualified for having a particular skills speaking is the only important thing is needed. Thus, those audience do not enjoy his presentation means that some problem is occuring in the situation, let say that the audience is being laughed or even mocked openly for his dialect because he is not usual to explain something with formal so that he hesitant to speak out in front of those audience. Therefore it makes the presentation become chaos cause the audience are not focus on the material but they only focus toward his fault.. If experience like these are the reason behind their hesitancy to speak out in class, this signifies a problem on the office that merits attention (Dunstan \& Jaeger, 2015). (Collins et al., 2009) also noted that a student who perceived their own speech to a divergent from campus norms were hesitant to speak in class.

Making comfortable for the audience is the first duty for presenter to deliver their speech in front of them. Sometimes audience want something that we need to guess what they are really need and what kind of way that make them understand enough as to the material. This things should exist on the presenter's mind that the particular thing that bring him fall down and feeling dissapointment will be coming up after they relize that he did not prepared yet for facing those things. Primarily when the presenter is not experienced enough to deliver some thing in front of people by using formal language, it is all the better for him to ignore the offering become presenter. This become their self-awareness toward facing something that never do by a person. So that it is why the speaking skill become crucial thing that a presenter should possess.

\section{METHOD}

The method of qualitative research is a case that is examined to be able to understand a phenomenon in depth, detail, and context is often done by focusing on smaller samples, compared to large samples of interest to help researchers search for general law (Yazan \& De Vasconcelos, 2016). This methodological aspect of the research is explored to answer the two research questions: How dialect could be influenced by students language potential? What make student's dialect could not be changed easily remember that dialect could decide that whether or not a person is qualified to deliver something in front of people?

Within the qualitative research paradigm, 'descriptive' was chosen as a term to represent the research design regarding the following feature that has relevant toward the study. First, this 
tudy was used to obtain information concerning the current status of the phenomena (Costa, 2008). The research conducted at IKIP Siliwangi Bandung, at Cimahi, West Java Province, Indonesia. The researcher gain the data by accomodate students in learning process. In the class there were 35 students who consist of 22 female and 13 male, the class is not big in the other hand the students capacity is sufficient to enter the class by the amount of students. The researcher gain information from 11 students in the class using the questionnaire. Also the researcher adapted the questionnaire from Govender R, Lee MT, Drinnan M, Davies T, Twinn C \& Hilari K. (2015). The questionnaire consists of 10 questions.

\section{RESULTS AND DISCUSSION}

\section{Results}

The researcher did the research and got the complete data from all research instruments through online questionnaire. It provides ten questions from eleven responses from 3 different tribes (Sundanese, Minangnese and Javanese). Sundanese is a group of people who live in West Java, Minangnese is a group of people who come from West Sumatera and Javanese is a group of people who live in Central Java. The researcher had analyzed the data to obtain the objectives of the research. Here are the draw of the questionnaire had been answer by all responses, as follow:

Table1 1.

Most of Responses Are Understand About Dialect

\begin{tabular}{|l|l|l|l|l|l|}
\hline NO & QUESTIONS & YES & $\begin{array}{l}\text { A } \\
\text { LITTLE }\end{array}$ & $\begin{array}{l}\text { A } \\
\text { LOT }\end{array}$ & $\begin{array}{l}\text { I DON'T / I DON'T THINK SO } \\
\text { (NEGATIVE ANSWER) }\end{array}$ \\
\hline $\mathbf{1}$ & $\begin{array}{l}\text { In your opinion, do you } \\
\text { understand what dialect } \\
\text { is }\end{array}$ & $\mathbf{6}$ & $\mathbf{4}$ & $\mathbf{1}$ & - \\
\hline
\end{tabular}

On the first question, most responses answered Yes that they understood of what dialect is. This means the question guide them to include the dialect on to the next question that have correlations to obtain the data in order to engage to other's point. This also reasonable answer that they may felt a bit understand of what dialect is, because the researcher did not give them a note about dialect's definition.

Table 2.

Most of Responses State That Dialect Have Relation With Mother Tongue

\begin{tabular}{|l|l|l|l|l|l|}
\hline NO & QUESTIONS & YES & $\begin{array}{l}\text { A } \\
\text { LITTLE }\end{array}$ & $\begin{array}{l}\text { A } \\
\text { LOT }\end{array}$ & $\begin{array}{l}\text { I DON'T / I DON'T THINK SO } \\
\text { (NEGATIVE ANSWER) }\end{array}$ \\
\hline $\mathbf{2}$ & $\begin{array}{l}\text { Do you agree that } \\
\text { dialect have relation } \\
\text { with mother tongue? }\end{array}$ & $\mathbf{6}$ & $\mathbf{2}$ & $\mathbf{1}$ & $\mathbf{2}$ \\
\hline
\end{tabular}

To ascertain that the dialect deal with mother tongue. The second question exhibit that most responses agree on this opinion. As we know both of them have the same definition that is a language which is used in a certain of region or social group. This actually mean dialect have correlation with mother tongue. 
Table 3.

Most of Responses Have A Problem In English Speaking

\begin{tabular}{|l|l|l|l|l|l|}
\hline NO & QUESTIONS & YES & $\begin{array}{l}\text { A } \\
\text { LITTLE }\end{array}$ & $\begin{array}{l}\text { A } \\
\text { LOT }\end{array}$ & $\begin{array}{l}\text { I DON'T / I DON'T THINK SO } \\
\text { (NEGATIVE ANSWER) }\end{array}$ \\
\hline $\mathbf{3}$ & $\begin{array}{l}\text { As English is Foreign } \\
\text { Language. Do you } \\
\text { have a problem when } \\
\text { you speak in English? }\end{array}$ & $\mathbf{6}$ & $\mathbf{5}$ & - & - \\
\hline
\end{tabular}

All of the responses are agree on the question number 3 in which they have problem to speak with different level. The responses who choose A Little means their level are higher than the responses who choose Yes. This question seen making category among the responses.

Table 4.

Most of Responses Think That The Problem Is Not Come From Their Custom

\begin{tabular}{|l|l|l|l|l|l|}
\hline NO & QUESTIONS & YES & $\begin{array}{l}\text { A } \\
\text { LITTLE }\end{array}$ & $\begin{array}{l}\text { A } \\
\text { LOT }\end{array}$ & $\begin{array}{l}\text { I DON'T / I DON'T THINK SO } \\
\text { (NEGATIVE ANSWER) }\end{array}$ \\
\hline $\mathbf{4}$ & $\begin{array}{l}\text { Do you think that your } \\
\text { problem comes from } \\
\text { your custom } \\
\text { (Sundanese, Javanese, } \\
\text { Bataknese, } \\
\text { Minangnese)? }\end{array}$ & - & $\mathbf{1}$ & $\mathbf{1}$ & $\mathbf{9}$ \\
\hline
\end{tabular}

To analyze the speaking problem, question number 4 indicates the more responses using mother tongue so that it influences the responses' difficulties to speak English. In fact, most of the responses disagree that the problem is not come from their custom.

Table 5.

Most of Responses Understand While They Are Talking To A Person Who Has Strong Dialect

\begin{tabular}{|l|l|l|l|l|l|}
\hline NO & QUESTIONS & YES & $\begin{array}{l}\text { A } \\
\text { LITTLE }\end{array}$ & $\begin{array}{l}\text { A } \\
\text { LOT }\end{array}$ & $\begin{array}{l}\text { I DON'T / I DON'T THINK SO } \\
\text { (NEGATIVE ANSWER) }\end{array}$ \\
\hline $\mathbf{5}$ & $\begin{array}{l}\text { As you know that we } \\
\text { have so many different } \\
\text { classmates who comes } \\
\text { from different custom, } \\
\text { Did you understand if } \\
\text { your friend who have } \\
\text { strong custom dialect } \\
\text { (speak English using } \\
\text { Sundanese intonation) } \\
\text { telling story in English? }\end{array}$ & $\mathbf{7}$ & $\mathbf{3}$ & $\mathbf{1}$ & - \\
\hline
\end{tabular}

We have question number 5 . In this question the researcher would like to obtain information that whether or not speaking English using custom dialect influence them as interlocutor are difficult to understand. In fact, this is not such a problem for all the responses. There was no answer that indicate the responses did not understand at all. 
Table 6.

Most of Responses Argue That Dialect Is Not The Problem

\begin{tabular}{|l|l|l|l|l|l|}
\hline NO & QUESTIONS & YES & $\begin{array}{l}\text { A } \\
\text { LITTLE }\end{array}$ & $\begin{array}{l}\text { A } \\
\text { LOT }\end{array}$ & $\begin{array}{l}\text { I DON'T / I DON'T THINK SO } \\
\text { (NEGATIVE ANSWER) }\end{array}$ \\
\hline $\mathbf{6}$ & $\begin{array}{l}\text { If so, do you agree if } \\
\text { dialect is not the } \\
\text { problem? }\end{array}$ & $\mathbf{9}$ & $\mathbf{2}$ & - & - \\
\hline
\end{tabular}

From question number 6, all responses stated that dialect is not such a problem when a person has custom dialect and try to speak English. As long as the person able to speak English even with their own dialect, there will be no any justification that the person is unable to speak.

Table 7.

Most of Responses Argue That Critical Thinking Is The One of Language Potential

\begin{tabular}{|l|l|l|l|l|l|}
\hline NO & QUESTIONS & YES & $\begin{array}{l}\text { A } \\
\text { LITTLE }\end{array}$ & $\begin{array}{l}\text { A } \\
\text { LOT }\end{array}$ & $\begin{array}{l}\text { I DON'T / I DON'T THINK SO } \\
\text { (NEGATIVE ANSWER) }\end{array}$ \\
\hline $\mathbf{7}$ & $\begin{array}{l}\text { People have language } \\
\text { potential to speak } \\
\text { because they use } \\
\text { critical thinking. How far } \\
\text { do you agree? }\end{array}$ & $\mathbf{5}$ & $\mathbf{3}$ & $\mathbf{3}$ & - \\
\hline
\end{tabular}

The question number 7 answer the problem, obviously dialect is not a problem for the English language learners but the problem is on their language potential. Critical thinking always be used when person should answer the question, determine what the question was, and how the sentence could be constructed. Most of them have the same feeling and experience that they stated agree on the argument.

Table 8.

Most of Responses Think That Dialect And Language Potential Are Influenced Each

Other

\begin{tabular}{|l|l|l|l|l|l|}
\hline NO & QUESTIONS & YES & $\begin{array}{l}\text { A } \\
\text { LITTLE }\end{array}$ & $\begin{array}{l}\text { A } \\
\text { LOT }\end{array}$ & $\begin{array}{l}\text { I DON'T / I DON'T THINK SO } \\
\text { (NEGATIVE ANSWER) }\end{array}$ \\
\hline $\mathbf{8}$ & $\begin{array}{l}\text { If you have a friend } \\
\text { who have strong } \\
\text { custom dialect (speak } \\
\text { English using } \\
\text { Sundanese intonation) } \\
\text { but as long as your } \\
\text { friend can speak } \\
\text { English and make the } \\
\text { audience really engage } \\
\text { on his explanation. } \\
\text { How far do you agree } \\
\text { that dialect could be } \\
\text { influenced by language } \\
\text { potential? }\end{array}$ & $\mathbf{5}$ & $\mathbf{6}$ & - & - \\
\hline
\end{tabular}

On the question number 8 , most of all the responses answer agree in the statement. This means when the performer speak English using Sundanese intonation for the example, the listener still 
understand because the performer have language potential that could be cover the dialect the performer used. So that dialect could be influenced by language potential.

Table 9.

Almost The Responses Think That Practice Makes English Inonation Perfect

\begin{tabular}{|l|l|l|l|l|l|}
\hline NO & QUESTIONS & YES & $\begin{array}{l}\text { A } \\
\text { LITTLE }\end{array}$ & $\begin{array}{l}\text { A } \\
\text { LOT }\end{array}$ & $\begin{array}{l}\text { I DON'T / I DON'T THINK SO } \\
\text { (NEGATIVE ANSWER) }\end{array}$ \\
\hline $\mathbf{9}$ & $\begin{array}{l}\text { If you try to change } \\
\text { your dialect to English. } \\
\text { It means you need to } \\
\text { practice to use English } \\
\text { intonation more often. } \\
\text { How far do you agree? }\end{array}$ & $\mathbf{9}$ & - & $\mathbf{2}$ & - \\
\hline
\end{tabular}

On the question number 9 , all of the responses are agree that practice makes perfect. The more learner practice the more learner have the language capability. As we know that intonation is form of language capability so that it is important to be used. For the example the learner uses Minangnese when speaking English, then you may ask to the learner that did the learner practice English intonation when he speaks? Often times, the learner who have strong dialect custom are rarely to learn the English intonation whereas the learner could practice by imitating a native speaker, watching movie with Americould/Britain actor and actress and many more.

Table 10.

Most of The Responses Think That A Qualified Speaker Could Be Decided By Best Language Intonation The Speaker Use

\begin{tabular}{|l|l|l|l|l|l|}
\hline NO & QUESTIONS & YES & $\begin{array}{l}\text { A } \\
\text { LITTLE }\end{array}$ & $\begin{array}{l}\text { A } \\
\text { LOT }\end{array}$ & $\begin{array}{l}\text { I DON'T / I DON'T THINK SO } \\
\text { (NEGATIVE ANSWER) }\end{array}$ \\
\hline $1 \mathbf{1 0}$ & $\begin{array}{l}\text { Whether an English } \\
\text { speaker is qualified. It } \\
\text { marks on the usage of } \\
\text { language intonation. Do } \\
\text { you agree? }\end{array}$ & $\mathbf{7}$ & $\mathbf{2}$ & $\mathbf{1}$ & $\mathbf{1}$ \\
\hline
\end{tabular}

In respondent's column of this final question are filled, there is a comparison between the responses who agree and disagree namely 10:1. Because most of responses choose agree, it means this statement is accepted that language intonation is important to obtain as qualified English speaker.

\section{Discussion}

From the findings, the researcher provides the question determining about whether dialect is the one which influence student's language potential or is there any particular of student's problem in English speaking except dialect. In addition, critical thinking and English intonation training program are the factors to obtain the accurate data. Indeed, this research stated dialect is not the problem of student's potential to speak English. Therefore, the problem comes from their critical thinking and less practice to gain English intonation in terms of English speaking capability. The data was analyzed in order to draw conclusion as to The Influence Between Student Language Potential With Their Own Dialect. In short, this finding is constructed from two parts. They would be described as follows:

Student's Language Potential Through Critical Thinking 
Looking at the needs to develop critical thinking is not such convenient things. However, things need to be consider is systematic planning. This means to implement the skill, planning of teaching method carefully and assessment is imperative (Husna, 2019). The three keys combine the information as to the experience in the class that presenting a presentation task given by a lecturer to students. There would be a chance for the presenter and audience implementing the skill such as speaking and listening. The presenter exhibit chapter 1 in the subject matter they supposed to explain. How does the presenter make the best explanation in order to make the audience engage (produce question to gain the curious point) and could this teaching method be accepted by the lecturer? It becomes their target as the cycle of systematic planning. After all, the presenter would obtain mark especially some feedback from the lecturer about the performance.

According to the data collection, on the question number 7 that using critical thinking have similar meaning with people who have language potential. Nevertheless, the researcher believes that this systematic planning would make student's critical thinking develop if doing through the regulations very often.

Student's Language Potential Through Dialect

Sundanese, Bataknese, Minangnese and Javanese people need a time to learn a foreign language such as English. They have strong custom dialect while speaking, this impact while speaking English. So that, learning English intonation is important as well.

Dialect is the characteristics of every person that include of student's language potential. Language potential is language variant parts which combine to be a characteristics of human who live in certain group that has the same character. These example of language variant parts are different pronunciation of words, grammatical, orthography, vocabulary and language intonation. This is the form of language which construct the language potential.

Dealing with language learner, student who is new comer to be an English learner in school, they still have language potential even if his dialect is strong. It is no such a big problem for the student who has strong dialect as a learner. Student should practice more to develop his skill on English speaking.

\section{CONCLUSION}

Having a fair arguments and producing some questions to get more knowledge is people desire to do a great attention on something information. Those skills could be obtained through some practice in advance. However, student is not having the skill suddenly. Enjoy the process by passing through some obstacle, practice more speaking, learn English intonation, make a question, make an argument, doing assessment to evaluate self-skill are what to include of obtaining the skill. Those things could develop critical thinking and therefore, student could speak better as the teacher's expectation.

\section{ACKNOWLEDGMENTS}

The authors are thankful to the institution (IKIP Siliwangi) and English Education Study Programme especially for the lecturers who helped the author that published this article. This research I dedicated to beloved my paretns who supporting the author to finish and publish this project as well. 


\section{REFERENCES}

Aprianti, I. N., \& Parmawati, A. (2020). Derivational And Inflectional Morpheme Analysis On The Song Lyrics Of Lady Gaga “A Star Is Born” Album. PROJECT (Professional Journal of English Education), 3(3), 322-328.

Arjuna, G. (2016). Journal of English Language Teaching The Use Of Problem-Based Learning Method In. 5(1).

Collins, E. C., Biernat, M., \& Eidelman, S. (2009). Stereotypes in the communication and translation of person impressions. Journal of Experimental Social Psychology. https://doi.org/10.1016/j.jesp.2008.09.005

Costa, D. M. N. (2008). Can creativity be formalized? Peircean reflections on the role of abduction in human intelligence. In Toward Artificial Sapience: Principles and Methods for Wise Systems. https://doi.org/10.1007/978-1-84628-999-6_1

Dunstan, S. B., \& Jaeger, A. J. (2015). Dialect and influences on the academic experiences of college students. Journal of Higher Education. https://doi.org/10.1353/jhe.2015.0026

Li, B., Sainath, T. N., Sim, K. C., Bacchiani, M., Weinstein, E., Nguyen, P., Chen, Z., Wu, Y., $\&$ Rao, K. (2018). Multi-Dialect Speech Recognition with a Single Sequence-to-Sequence Model. ICASSP, IEEE International Conference on Acoustics, Speech and Signal Processing - Proceedings. https://doi.org/10.1109/ICASSP.2018.8461886

Mallinson, C., Charity Hudley, A., Strickling, L. R., \& Figa, M. (2011). A conceptual framework for promoting linguistic and educational change. Linguistics and Language Compass. https://doi.org/10.1111/j.1749-818X.2011.00289.x

Mawadda Warohma, A., Kurniasari, P., Dwijayanti, S., Irmawan, \& Yudho Suprapto, B. (2018). Identification of Regional Dialects Using Mel Frequency Cepstral Coefficients (MFCCs) and Neural Network. Proceedings - 2018 International Seminar on Application for Technology of Information and Communication: Creative Technology for Human Life, ISemantic 2018. https://doi.org/10.1109/ISEMANTIC.2018.8549731

Rahmawati, R., \& Lestari, D. P. (2018). Java and Sunda dialect recognition from Indonesian speech using GMM and I-Vector. Proceeding of 2017 11th International Conference on Telecommunication Systems Services and Applicatfile:///D:/Dialect/Newest/Java and $\begin{array}{llll}\text { Sunda Dialect Recognition from.Pdfions, } & \text { TSSA } & 2017 .\end{array}$ https://doi.org/10.1109/TSSA.2017.8272892

Yazan, B., \& De Vasconcelos, I. C. O. (2016). Three approaches to case study methods in education: Yin, Merriam, and Stake. Meta: Avaliacao. https://doi.org/10.22347/21752753v8i22.1038 